Article

\title{
Does Cysteine Rule (CysR) Complete the CendR Principle? Increase in Affinity of Peptide Ligands for NRP-1 Through the Presence of N-Terminal Cysteine
}

\author{
Anna K. Puszko 1미 ${ }^{1}$ Piotr Sosnowski ${ }^{2}$, Françoise Raynaud ${ }^{3,4,5}$, Olivier Hermine ${ }^{3,4,5}$, \\ Gérard Hopfgartner ${ }^{2}$, Yves Lepelletier ${ }^{3,4,5, * \mathbb{D}}$ and Aleksandra Misicka ${ }^{1,6, *(\mathbb{D})}$ \\ 1 Faculty of Chemistry, University of Warsaw, Pasteura 1, 02-093 Warsaw, Poland; apuszko@chem.uw.edu.pl \\ 2 Department of Inorganic and Analytical Chemistry, University of Geneva, 24 Quai Ernest Ansermet, \\ CH-1211 4 Geneva, Switzerland; piotr.sosnowski@unige.ch (P.S.); gerard.hopfgartner@unige.ch (G.H.) \\ 3 Imagine Institute, Université de Paris, 24 boulevard Montparnasse, 75015 Paris, France; \\ francoisechamp94@gmail.com (F.R.); ohermine@gmail.com (O.H.) \\ 4 INSERM UMR 1163, Laboratory of Cellular and Molecular Basis of Normal Hematopoiesis and \\ Hematological Disorders: Therapeutical Implications, 24 boulevard Montparnasse, 75015 Paris, France \\ 5 CNRS ERL 8254, 24 boulevard Montparnasse, 75015 Paris, France \\ 6 Department of Neuropeptides, Mossakowski Medical Research Centre, Polish Academy of Sciences, \\ Pawinskiego 5, 02-106 Warsaw, Poland \\ * Correspondence: y.lepelletier@gmail.com (Y.L.); misicka@chem.uw.edu.pl (A.M.); \\ Tel.: +33-14275-4283 (Y.L.); +48-22-552-6424 (A.M.)
}

Received: 31 January 2020; Accepted: 5 March 2020; Published: 13 March 2020

\begin{abstract}
The structure-activity relationship of branched H-Lys( $h$ Arg)-Dab-Dhp-Arg-OH sequence analogues, modified with Cys-Asp or Cys at N-terminal amino acids (Lys, hArg), in VEGF- $_{165} /$ Neuropilin-1 complex inhibition is presented. The addition of Cys residue led to a 100 -fold decrease in the $\mathrm{IC}_{50}$ value, compared to the parent peptide. The change occurred regardless of coupling Cys to the free N-terminal amino group present in the main or the side chain. A few analogues extended by the attachment of Cys at the N-terminus of several potent NRP-1 peptide ligands documented in the literature are also presented. In all studied cases, the enhancement of inhibitory properties after the addition of Cys at the $\mathrm{N}$-terminus is observed. It is particularly evident for the tetrapeptide derived from the C-terminus of VEGF- $\mathrm{A}_{165}$ (KPRR), suggesting that extending the K/RXXK/R motif (CendR) with the Cys moiety can significantly improve affinity to NRP-1 of CendR peptides.
\end{abstract}

Keywords: Neuropilin-1; VEGF- $\mathrm{A}_{165}$; VEGF- $\mathrm{A}_{165} / \mathrm{NRP}-1$ complex; protein-ligand interaction; peptide ligands

\section{Introduction}

Neuropilin-1 (NRP-1) is a cell surface receptor involved in the development of axon guidance and also in physiological, as well as pathological, angiogenesis processes, including cancer [1-3]. NRP-1, as a co-receptor for class 3 semaphorin and multiple growth factors, including epidermal growth factor (EGF), vascular endothelial growth factor (VEGF), PDGF, platelet-derived growth factor (PlGF), hepatocyte growth factor (HGF), and transforming growth factor $\beta$ (TGF- $\beta$ ), cooperatively enhances the activity of the respective receptor tyrosine kinases (RTKs) in cell signaling systems [4]. Vascular endothelial growth factor $\mathrm{A}_{165}\left(\mathrm{VEGF} \mathrm{A}_{165}\right)$ is considered to be the most significant modulator of angiogenesis [5-7], and NRP-1 enhances its binding to VEGFR-2 [8,9]. There is evidence that NRP-1, despite the lack of catalytic activity, also serves as an independent mediator of blood vessel 
development in cancerous tumors and that its expression on the surface of cancerous cells is increased and often associated with poor prognosis [10-13]. These results indicate that searching for new NRP-1 inhibitors of pathological angiogenesis, including functional peptides, could play a crucial role in drug development (e.g., in oncology).

The VEGF-A 165 fragment encoded by exons 7 and 8 is mainly responsible for protein interaction with NRP-1 [14-17]. The binding pocket of the NRP-1 b1 domain is shallow, and only the C-terminal Arg of the ligand is able to directly enter into it $[6,18]$. Screening of phage libraries led to the identification of peptides possessing a R/KXXR/K consensus motif embedded in their terminal sequence, which showed a high binding affinity to NRP-1 [18]. As with VEGF-A 165 , the C-terminal Arg (or rarely, Lys) was important for NRP-1-binding. Blocking the free carboxyl group of this Arg residue by amidation or adding another amino acid eliminated ligand binding to the receptor. The strict requirements of the $\mathrm{R} / \mathrm{KXXR} / \mathrm{K}$ C-terminal structural motif in NRP-1 peptidic ligands is called the C-end rule (CendR) [19]. The CendR fragment is present in the structure of active peptidic NRP-1 ligands described in the literature, e.g., heptapeptide A7R (ATWLPPR) [19-21], shorter analogues of A7R [22], tuftsin [23], and penetrating iRGD peptide [24] as well as the C-terminus of VEGF-A 165 (CDKPRR) encoded by the exon 8 and multiple viruses' capsid proteins, e.g., human T-cell lymphotropic virus type 1 (HTLV-1) [25,26] and Epstein-Barr virus (EBV) [27].

Another characteristic feature of the VEGF-A 165 structure is the presence of eight invariant cysteine (Cys) residues associated with intermolecular and intramolecular disulfide bonds [28]. The N-terminal fragment of the VEGF-A 165 domain ERTCDKPRR encoded by exons 7 and 8, as well as its shorter analogue CDKPRR, showed nearly $100 \%$ inhibition of the formation of the VEGF-A $165 / \mathrm{NRP}-1$ complex at a concentration of $100 \mu \mathrm{M}$ [29]. The replacement of Cys with Ser at positions 4 and 6 of the former peptide and deletion of Cys in the latter sequence caused a significant decrease in the affinity for NRP-1. These results suggested that Cys may have a key role, adjacent to the CendR motif, in NRP-1 interaction. Various types of ligand-receptor interactions involving the thiol group of Cys residues are described in the literature. Experimental and theoretical evidences indicate that $C y s$ can be a hydrogen bond donor and/or acceptor, where its hydrogen-bonding interactions influence reactivity and, thus, biological functions [30,31]. The strength of the hydrogen bond to the Cys thiol/thiolate (-SH/-S ${ }^{-}$) depends also on its hydrogen-bonding partner and its local environment. There is also a clear tendency of the sulphur atom to interact with the surface of the aromatic ring (S- $\pi$ interaction) [30,32-34]. Thiol-disulfide exchange reactions between ligand-containing Cys and the protein may also occur $[35,36]$. All of these interactions may play a crucial role in the formation of the ligand-receptor complex.

Among the antiangiogenic molecules, a groundbreaking discovery was the A7R heptapeptide, isolated using phage display library screening, which in vivo decreases breast cancer angiogenesis and growth [19-21]. Based on the A7R peptide, which showed the ability to inhibit VEGF-A $165 / \mathrm{NRP}_{-1}$ complex formation with a high $\mathrm{IC}_{50}$ value $\left(\mathrm{IC}_{50}=80 \mu \mathrm{M}\right)[21]$, and respecting CendR rules, we previously obtained short-branched pentapeptides, with a general sequence $\mathrm{Lys}(h \mathrm{Arg})-\mathrm{AA}^{2}-\mathrm{AA}^{3}-\mathrm{Arg}$, that have reduced $\mathrm{IC}_{50}$ values $\left(\mathrm{IC}_{50}=2-20 \mu \mathrm{M}\right)$ [37,38]. In the present study, we decided to examine how an additional Cys-Asp (CD) fragment (present at the N-terminus of the C-terminal hexapeptide of VEGF-A $165-C D K P R R)$ or Cys (C) residue will influence affinity for NRP-1 of the best analogue of our branched peptides, namely Lys(hArg)-Dap-Dhp-Arg. Following this strategy, four analogues were designed and synthesized. The parent branched peptide has two free amino groups at N-terminus: one in the main chain ( $\alpha$-amino group of Lys) and the second one in the branched part of the molecule ( $\alpha$-amino group of hArg). Thus, we designed analogues in which additional Cys-Asp or Cys were placed in both positions. Enzymatic stability studies were performed for the most promising branched peptides. Moreover, to further evaluate the effect of the cysteine addition, linear peptidic ligands based on active compounds described in the literature, with additional Cys on the N-terminus, were synthesized and tested for affinity to NRP-1. 


\section{Materials and Methods}

\subsection{Materials}

Unless otherwise specified, reagents were obtained from commercial sources and used without further purification. Fmoc-Arg(Pbf) Wang resin was purchased from Activotec (Cambridge, UK). Amino acids and coupling reagents were obtained from Iris Biotech (Marktredwitz, Germany). Solvents and reagents were purchased from Merck (Darmstadt, Germany). Recombinant human NRP-1 and biotinylated human VEGF-A165 were purchased from R\&D Systems (Minneapolis, MN, USA). Chemiluminescent substrate was purchased from Thermo Scientific (Waltham, MA, USA). Luminescence was measured using a Tecan Infinite F200Pro microplate reader (Männedorf, Switzerland).

\subsection{Peptides Synthesis}

The synthesis of all peptides was carried out manually on the preloaded Fmoc-Arg(Pbf) Wang resin with a capacity of $0.39 \mathrm{mmol} / \mathrm{g}(0.5 \mathrm{~g})$ following the Fmoc chemistry. Coupling of 2 eq amino acids $(0.4 \mathrm{mmol})$ was done using 2 eq HATU $(0.4 \mathrm{mmol})$ and 5 eq DIPEA $(1 \mathrm{mmol})$ in DMF $(5 \mathrm{~mL})$. Completion of coupling was checked using a Kaiser or chloranil test. Fmoc deprotection step was done using 20\% piperidine in DMF. Tetrakis(triphenylphosphine)palladium(0) (0.016 mmol; $0.1 \mathrm{eq})$ in the presence of $20 \mathrm{eq} \mathrm{PhSiH}_{3}(3.2 \mathrm{mmol})$ in DCM was used for the Alloc deprotection step. Final compounds were cleaved from the resin with the use of $5 \mathrm{~mL}$ TFA:DTT:H 2 O:TIS (88:5:5:2, v:w:v:v) for $3 \mathrm{~h}$ and then precipitated by a dropwise addition into a cold diethyl ether. Synthesized compounds were purified on a Shimadzu Prominence preparative HPLC system (Duisburg, Germany) equipped with a Phenomenex Jupiter Proteo C12 90 AXIA A $10 \mu \mathrm{m} 250 \times 21.2$ mm column (Torrance, CA, USA). Pure compounds were analyzed with the Shimadzu Prominence analytical HPLC system (Duisburg, Germany) and Sciex 6600TOF mass spectrometer (Concord, Ontario, Canada). Detailed analytical method description and data for purified compounds (HPLC-UV, HRMS and HRMS/MS) are available in the Supplementary Materials.

\subsection{Competitive NRP-1-Binding Assay}

The method used was similar to the one previously described [29,38-41]. The first step was a coating of a 96-well plate using $100 \mu \mathrm{L}$ (200 ng/well) of recombinant human NRP-1. After overnight incubation at $4{ }^{\circ} \mathrm{C}$, nonspecific binding was blocked with $0.5 \%$ BSA in PBS. Next, $50 \mu \mathrm{L}$ of peptide in PBS in selected concentrations and $50 \mu \mathrm{L}$ of human $(\mathrm{bt})-V_{E G F} \mathrm{~A}_{165}(400 \mathrm{ng} / \mathrm{mL})$ in PBS containing $4 \mu \mathrm{g} / \mathrm{mL}$ of heparin were added and incubated for $2 \mathrm{~h}$ at r.t. After washing, wells were treated with streptavidin-horseradish peroxidase conjugate in PBS (1:8000) for $45 \mathrm{~min}$. Final washing was followed by an addition of $100 \mu \mathrm{L}$ chemiluminescent substrate and the immediate quantitative determination of the luminescence. Wells incubated with (bt)-VEGF-A 165 only served as a positive control (P), while not-coated by NRP-1 wells were used for a negative control (NS). Percentages of inhibition were calculated by the following formula:

$$
100 \%-[[(\mathrm{S}-\mathrm{NS}) /(\mathrm{P}-\mathrm{NS})] \cdot 100 \%]
$$

where $S$ is the signal intensity obtained from wells incubated with the peptide. Presented data are the mean \pm SEM of two or three independent experiments, each performed in triplicate.

\subsection{Degradation Assay in Human Plasma}

This assay was performed according to the method described previously [38,41]. First, human blood plasma was preactivated in an Eppendorf ThermoMixer ${ }^{\circledR}$ Comfort (Hamburg, Germany) for $20 \mathrm{~min}$ at $37{ }^{\circ} \mathrm{C}(350 \mathrm{rpm})$. Next, the peptide dissolved in water $(6 \mathrm{mg} / \mathrm{mL} ; 5 \mu \mathrm{mol} / \mathrm{mL})$ was mixed with human plasma $(\sim 1 \mu \mathrm{mol} / \mathrm{mL}$ final concentration) and incubated in the same conditions. 
One-hundred microliters of the mixture was collected in 1.5-mL microtubes at selected time intervals $(0-96 \mathrm{~h})$, followed by protein precipitation by adding $100 \mu \mathrm{L}$ of $98 \%$ ethanol and by vortexing for 1 $\min \left(3000 \mathrm{~min}^{-1}\right)$. Samples were centrifuged for $10 \mathrm{~min}$ at $4{ }^{\circ} \mathrm{C}(11,000 \mathrm{~g})$, and $100 \mu \mathrm{L}$ of supernatant was collected and lyophilized. Reconstituted in $100 \mu \mathrm{L}$ of water, samples were subjected to RP-HPLC analysis. LC-MS analyses with a Shimadzu LCMS-2020 mass spectrometer (Duisburg, Germany) were done for selected samples. A detailed description of the method can be found in the Supplementary Materials. All results are represented as an average, with error bars indicating \pm SEM determined from the results of two independent experiments performed in duplicates.

\subsection{Statistical Analysis}

$\mathrm{IC}_{50}$ of the peptides were calculated using the nonlinear regression function with Prism (GraphPad Software, San Diego, CA, USA). The same software was used to calculate and present the plasma stability assay results. All results are represented as an average, with error bars indicating \pm SEM.

\subsection{Ethics}

The study was conducted in full accordance with ethical principles in accordance with the ICH E6 (R2) Guideline for Good Clinical Practice and the Code of Good Customs in Science developed by the Polish Academy of Sciences. The Rector's Commission for Ethics of Scientific Research with Human Participation, University of Warsaw, Warsaw, Poland gave the ethical approval (approval no. 51/2020). A signed consent for using plasma was obtained from volunteers.

\section{Results and Discussion}

\subsection{Peptides Synthesis}

The synthesis of compounds was carried out on the preloaded Fmoc-Arg(Pbf)-Wang resin following the Fmoc chemistry (Scheme 1) [42]. The standard coupling HATU/DIPEA protocol was used [43]. The obtained compounds were cleaved from the resin using the TFA:DTT: $\mathrm{H}_{2} \mathrm{O}: \mathrm{TIS}$ mixture, purified, and analyzed using RP-HPLC, HRMS, and HRMS/MS.

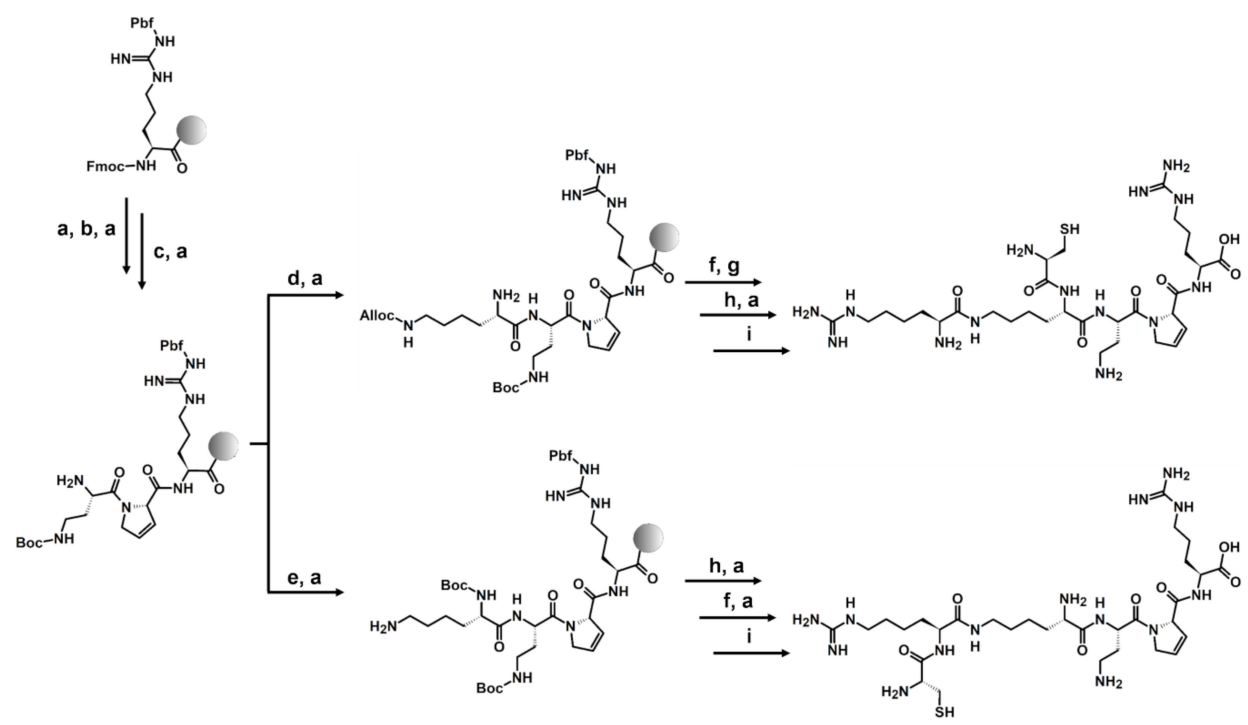

Scheme 1. The solid-phase peptide synthesis (SPPS) strategy on the example of peptides 3 and 4: (a) 20\% piperidine in DMF; (b) 2 eq Fmoc-Dhp-OH, HATU, and DIPEA; (c) 2 eq Fmoc-Dab(Boc)-OH, HATU, and DIPEA; (d) 2 eq Fmoc-Lys(Alloc)-OH, HATU, and DIPEA; (e) 2 eq Boc-Lys(Fmoc), HATU, and DIPEA; (f) 2 eq Fmoc-Cys(Trt)-OH, HATU, and DIPEA; (g) $\mathrm{Pd}\left(\mathrm{PPh}_{3}\right)_{4}$ and $\mathrm{PhSiH}_{3}$; (h) 2 eq Fmoc- $h \operatorname{Arg}(\mathrm{Pbf})-\mathrm{OH}, \mathrm{HATU}$, and DIPEA; and (i) TFA:DTT:H ${ }_{2} \mathrm{O}: T I S$. 


\subsection{VEGF-A $A_{165} / N R P-1$ Complex Inhibition Assay}

Peptides were tested by the bt-VEGF-A $165 /$ NRP-1 complex inhibition assay with chemiluminescent detection, as previously described [29,38-41]. Assays of peptides $\mathbf{1}$ and 2, with additional Cys-Asp residues, have been carried out at concentrations between $0.1 \mu \mathrm{M}$ and $50 \mu \mathrm{M}$. The obtained results show a slight increase in the affinity of these analogues for the receptor relative to the parent sequence Lys(hArg)-Dab-Dhp-Arg $\left(\mathrm{IC}_{50}=4.3 \mu \mathrm{M}\right)$ (Table 1). For both compounds, the calculated $\mathrm{IC}_{50}$ value is two times lower, regardless of whether the Cys-Asp fragment was attached to the N-terminus $\left(\mathrm{IC}_{50}=2.5 \mu \mathrm{M}\right)$ or to the $h \mathrm{Arg}\left(\mathrm{IC}_{50}=2.0 \mu \mathrm{M}\right)($ Table 1$)$. Extending the sequence by a Cys-Asp fragment did not significantly reduce the $\mathrm{IC}_{50}$, but neither did it negatively affect the inhibitory properties of the compounds. It was therefore tested how the addition of only the Cys residue would affect the affinity of the parent peptide (PP) for the NRP-1 receptor. The amino acid was inserted in the same places as the Cys-Asp fragment previously. Compounds 3 and 4 were tested by the bt-VEGF- $\mathrm{A}_{165} / \mathrm{NRP}-1$ inhibition assay at 1-50 $\mu \mathrm{M}$ concentrations. However, results in this area did not allow the calculation of $\mathrm{IC}_{50}$. Only fluctuations in inhibition values for the given concentrations were observed within $~ 80 \%$, which occurs in the case of a range of concentrations in the flat area of the curve (plateau) describing the concentration-reaction relationship.

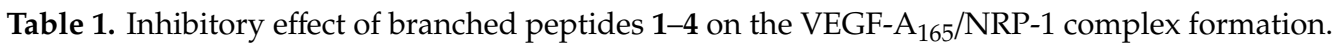

\begin{tabular}{cccc}
\hline Compound & \multicolumn{1}{c}{ Sequence } & $\log _{\mathbf{I C}}$ & IC $_{\mathbf{5 0}}(\boldsymbol{\mu M})$ \\
\hline $\mathbf{P P}^{\mathbf{1}}$ & H-Lys(hArg)-Dab-Dhp-Arg-OH & $-5.54 \pm 0.04$ & $4^{2} \mathbf{3}^{2}$ \\
\hline $\mathbf{1}$ & H-Cys-Asp-Lys( $h$ Arg)-Dab-Dhp-Arg-OH & $-5.60 \pm 0.03$ & 2.5 \\
$\mathbf{2}$ & H-Lys(Cys-Asp- $h$ Arg)-Dab-Dhp-Arg-OH & $-5.70 \pm 0.05$ & 2.0 \\
$\mathbf{3}$ & H-Cys-Lys(hArg)-Dab-Dhp-Arg-OH & $-7.079 \pm 0.1316$ & 0.08 \\
$\mathbf{4}$ & H-Lys(Cys- $h$ Arg)-Dab-Dhp-Arg-OH & $-7.194 \pm 0.0939$ & 0.06 \\
\hline
\end{tabular}

${ }^{1} \mathrm{PP}$, parent peptide. ${ }^{2}$ Data already published [38]. Unnatural amino acid abbreviations: Dab, 2,4-diaminobutyric acid and Dhp, 3,4-dehydroproline. Results are presented as the mean \pm SEM of two (peptides $\mathbf{1}$ and 2 ) or three independent experiments, each performed in triplicate.

We next adjusted the concentration range for compounds 3 and 4 and set it between $0.005-1 \mu \mathrm{M}$. The $\mathrm{IC}_{50}$ values obtained for both analogues, $80 \mathrm{nM}$ for compound 3 and $60 \mathrm{nM}$ for 4 , were two orders of magnitude lower than the PP. The small difference in affinity for NRP-1 between these compounds shows that the Cys residue has an extremely beneficial effect on their inhibitory ability, regardless of the selected amino acid positions.

Peptides containing a single Cys residue can form dimers by the oxidation of the cysteine side chain thiols, linking two chains together by a disulphide bridge. Disulphide bond formations may occur by air oxidation in a diluted aqueous solution of the peptide at a neutral $\mathrm{pH}$. To confirm that dimers were not formed during affinity assays, compounds 3 and 4 were incubated in PBS at $22{ }^{\circ} \mathrm{C}$ for $4 \mathrm{~h}$ to reproduce conditions during the ELISA-like test, and then samples were tested by RP-HPLC with UV detection. The results of these experiments showed that the dimerization of the compounds occurs minimally, at the level of $5 \%$ of the total concentration (peak area of dimer/monomer ratio); therefore, the obtained $\mathrm{IC}_{50}$ values were considered as results for the monomers (Figure 1).

Due to the positive results of Cys introduction into the parent-branched Lys(hArg)-Dab-Dhp-Arg peptide, new analogues, based on NRP-1 peptidic ligands known from the literature and with linear structures, were synthesized to test if an increase of their affinity for NRP-1 will also appear for a nonbranched sequence (Table 2). Designed compounds were modified by an $\mathrm{N}$-terminal addition of Cys to known tetrapeptides or by shortening the sequence of longer peptides to preserve the Cys-X-X-X-Arg motif. The first modified compound was the A7R peptide with an ATWLPPR sequence, which has been previously identified by the phage display technique and was shown to bind specifically to NRP-1 $\left(\mathrm{IC}_{50}=60-84 \mu \mathrm{M}\right)[19,21,38]$. This binding strongly inhibits the activation of NRP-1 by VEGF- $A_{165}$, and the LPPR sequence is responsible for $75 \%$ of this inhibition [44]. Since the LPPR 
peptide sequence is essential for the inhibition of VEGF activity, Cys on the N-terminus was added to this peptide fragment to preserve the Cys-X-X-X-Arg motif. Competitive assay results for peptide 5 show that sequence-shortening to the N-terminal tetrapeptide and the addition of Cys decreased $\mathrm{IC}_{50}$ seven-fold compared to the A7R peptide. Next, tuftsin (TKPR), which is an endogenous peptide that mimics the C-terminal tail of VEGF-A 165 and selectively binds to NRP-1 [23], was modified. Our data from the initial tests show that tuftsin's $\mathrm{IC}_{50}$ value is $100 \mu \mathrm{M}$, and this result coincides with the literature data [23]. This peptide is important due to a breakthrough in research on NRP-1, which was its co-crystallization with b1b2 subdomains' NRP-1 [45]. The results determined that a key fragment in the ligand-receptor interaction is the C-terminal Arg guanidine group. In this case, additional Cys on the N-terminus (peptide 6) increased ligand affinity more than 11-fold. The last tested compound was peptide 7 , based on the key fragment for VEGF-A $165 / \mathrm{NRP}-1$ interaction, the CDKPRR sequence encoded by exon $8[29,46]$. As we previously mentioned, the CDKPRR peptide blocked this interaction with percentages of inhibition of almost $100 \%$ at $100 \mu \mathrm{M}$, but the lack of Cys at the N-terminal (DKPRR) causes great deterioration of receptor affinity ( 20\% inhibition at $100 \mu \mathrm{M})[29,41]$. Compound 7 shows inhibition of the VEGF-A 165 /NRP-1 complex formation with $\mathrm{IC}_{50}=190 \mathrm{nM}$, which is an extraordinary improvement of its affinity (Table 2). Overall, the addition of Cys at the N-terminus enhances the affinity of tested peptides, showing that the cysteine rule (CysR) may be an important factor in optimizing active sequences.
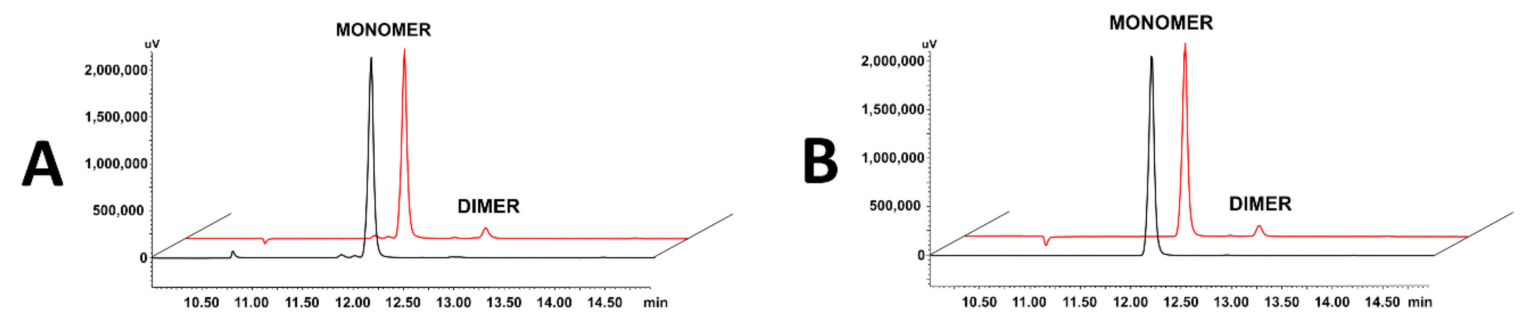

Figure 1. Superimposed chromatograms of peptides 3 (A) and 4 (B) incubated in PBS at $22{ }^{\circ} \mathrm{C}$ for $0 \mathrm{~h}$ (black) and $4 \mathrm{~h}$ (red).

Table 2. Inhibitory effects of known peptidic ligands from the literature, modified by a Cys addition at the C-terminus, on the VEGF-A $165 / \mathrm{NRP}-1$ complex formation.

\begin{tabular}{cccccc}
\hline Compound & Sequence & $\operatorname{logIC}_{\mathbf{5 0}}$ & IC $_{\mathbf{5 0}}(\boldsymbol{\mu M})$ & Reference Peptide $(\mathrm{RP}) \mathbf{R P}_{\mathbf{I C}}(\boldsymbol{\mu M})$ \\
\hline $\mathbf{5}$ & CLPPR & $-4.94 \pm 0.08$ & 11.4 & A7R $^{1}$ & $80(19,38)$ \\
$\mathbf{6}$ & CTKPR & $-5.03 \pm 0.08$ & 9.3 & Tuftsin $^{2}$ & $\geq 100(23)^{3}$ \\
$\mathbf{7}$ & CKPRR & $-6.727 \pm 0.762$ & 0.19 & DKPRR & $>>100(29,41)$ \\
\hline
\end{tabular}

${ }^{1}$ A7R sequence: ATWLPPR. ${ }^{2}$ Tuftsin sequence: TKPR. ${ }^{3}$ Obtained percentage inhibitory effect of tuftsin for the $100 \mu \mathrm{M}$ concentration was $46 \% \pm 3 \%$. Results are presented as the mean \pm SEM of two (peptides 5 and $\mathbf{6}$ ) or three independent experiments, each performed in triplicate.

\subsection{Enzymatic Stability in Human Plasma}

In addition to a high receptor affinity, enzyme resistance also plays an important role in the design of new biologically active compounds. Therefore, we performed in vitro enzymatic stability studies of peptides 3 and 4 in human blood plasma, to investigate whether the introduced Cys affected the half-life of the new compounds. Most peptidases, including those present in plasma, have certain preferences for cleavage regions. Many enzymes require a basic amino acid at the P1 position or small amino acids (Ala, Cys, Gly, and Ser) at the P1 and $\mathrm{P} 1^{\prime}$ positions for their action [47].

Compounds were incubated in human plasma at $37^{\circ} \mathrm{C}$, and at selected time intervals, samples were analyzed using RP-HPLC and LC-MS, as described previously [38,43]. Figure $2 \mathrm{~A}$ shows the concentration decline of each of the tested peptides during plasma incubation. After $24 \mathrm{~h}$, almost $50 \%$ of each compound's initial concentration was still present in the plasma. Following the next time intervals, we observed a significant degradation of peptide $3(\sim 20 \%$ after $96 \mathrm{~h})$ but a much slower decrease in the concentration of peptide $4(\sim 40 \%$ after $96 \mathrm{~h})$. This is probably due to the slower 
detachment of Cys residue from the side chain (peptide 4) compared to detachment from the main chain (peptide 3). Presented data show that additional Cys at the $\mathrm{N}$-terminus of the sequence reduced the enzymatic stability of the peptide compared to the parent peptide with $\mathrm{t}_{1 / 2}=51 \mathrm{~h}$ [38]. However, unmodified peptides tend to have short half-lives counted rather in minutes, e.g., ghrelin [48] and endomorphins [49], and modifications lead to extending this time often to only a few hours [49-51]. Thus, our results show that compounds $\mathbf{3}$ and $\mathbf{4}$ are relatively resistant to proteolytic enzymes.
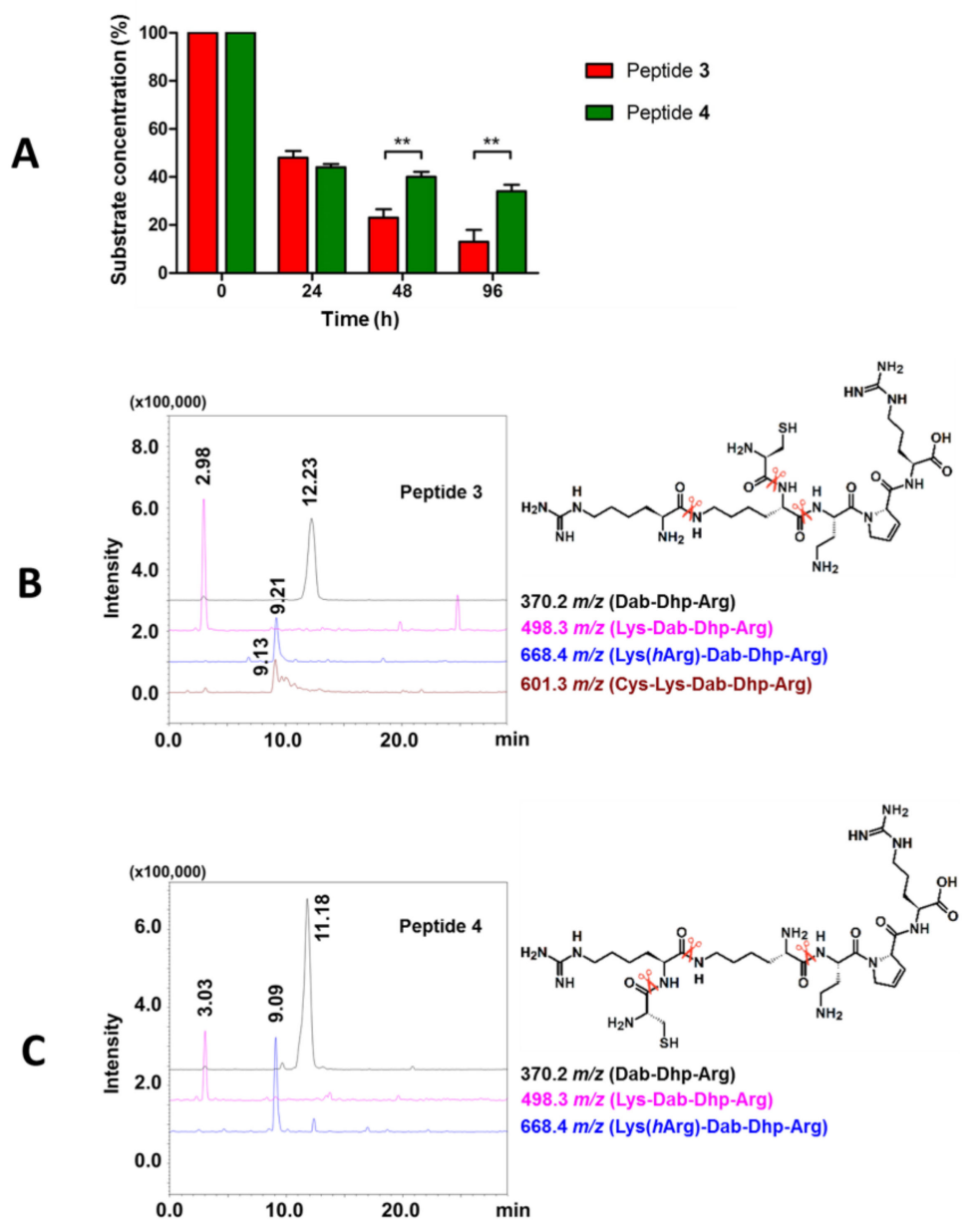

Figure 2. (A) Comparison of the in vitro metabolic stability of peptides 3 and 4 . Results are presented as the mean \pm SEM of two independent experiments performed in duplicates. Differences between peptides concentrations at various time intervals were analyzed by a two-way ANOVA with Bonferroni's post-tests (** $p<0.01)$. Extracted ion chromatograms (XICs) of detected metabolites and potential bonds cleaved by enzymes (scissors represent identified proteases cleavage sites) of (B) peptide 3 and (C) peptide 4 .

Identification of the metabolites was hampered by reactions occurring during incubation. Substrates and fragments with the thiol group could form disulphide bonds in various combinations; nevertheless, we determined, at least in part, which amide bonds undergo proteolysis. Enzymatic cleavage of the Cys-Lys/Cys-hArg, Lys- $\varepsilon-h A r g$, and Lys-Dab bonds were found (Figure 2B,C). Obtained RP-HPLC results show that, for both compounds, Cys is the first amino acid that is cleaved by enzymes (see Figures S9 and S11 in the Supplementary Materials). However, the site of attachment of the Cys residue seems to affect the resistance of the peptide. We hypothesize that compound 4 may have increased enzymatic resistance due to the Cys and $h$ Arg amide bond's limited accessibility for an enzymatic cleave. 


\section{Conclusions}

In this study, we have synthesized a new group of analogues based on our previously described branched H-Lys(hArg)-Dab-Dhp-Arg-OH sequence, which is a potent ligand of the NRP-1 receptor. We have now extended this sequence at the N-terminus with a Cys-Asp or Cys fragment. The addition of the Cys-Asp fragment, either at the N-terminus of the main or branched chain ( $\alpha$-amino group of Lys or $\alpha$-amino group of the $h \mathrm{Arg}$ ), decreased the affinity of the peptidomimetics to NRP-1 by approximately two-fold (peptides $\mathbf{1}$ and 2). However, elongation of the parent peptide by the Cys residue alone resulted in a significant 50 - and 70-fold decrease of the $\mathrm{IC}_{50}$ values for peptides 3 and 4 , respectively. This significant increase in the inhibitory effect occurred regardless of the place of the Cys attachment at the N-terminus. We also performed the enzymatic stability study of our best analogues, which demonstrated that our analogues are relatively stable in human plasma compared to natural active peptides, especially an analogue with Cys attached to the side chain (coupled with $h \mathrm{Arg}$ ).

Furthermore, we synthesized extended (Cys) analogues of several potent NRP-1 ligands documented in the literature. In all our experiments, we observed the enhancement of inhibitory properties after the addition of Cys. It was particularly evident for the peptide derived from the C-terminus of VEGF-A 165 (DKPRR), suggesting that extending the K/RXXK/R motif (CendR) with the Cys moiety can significantly improve the affinity to NRP-1 of the CendR peptides. The increase in the inhibitory properties of the peptides with Cys added at the N-terminus may be due to the possibility of additional interactions with NRP-1 through the SH group (hydrogen bond formation or ionic interaction). Thus, we assume that such observed enhancements of the inhibitory activity after the addition of Cys could be a more general rule, named in this report as CysR, which may complement the CendR rule, but the role of Cys in ligand-protein interactions still requires thorough investigation. The presented peptides have potential applications in drug design, but further studies should be performed. The next step will be the determination of the thiol group's importance in the ligand/NRP-1 interaction and optimization of the sulphur-containing side chain length. An important part of the research will be in vitro experiments which allow to prove that ligands bind to NRP-1 on cells' surfaces.

Supplementary Materials: The following are available online at http://www.mdpi.com/2218-273X/10/3/448/s1, Figures S1 and S2: HPLC-UV chromatogram of peptides 1-2 at $190 \mathrm{~nm}$, HRMS spectrum, and MS/MS fragmentation of $[\mathrm{M}+2 \mathrm{H}]^{2+}$, Figures S3-S7: HPLC chromatogram of peptides 3-7 at $190 \mathrm{~nm}$, HRMS spectrum, and MS/MS fragmentation of $[\mathrm{M}+\mathrm{H}]$, Figure S8: Dose-response curves of peptides 1-7, Figure S9: Full chromatogram of peptide 3 after degradation in different time intervals, Figure S10: Zoom-in peptide 3 signal after degradation in different time intervals, Figure S11: Full chromatogram of peptide 4 after degradation in different time intervals, Figure S12: Zoom-in peptide 4 signal after degradation in different time intervals, Table S1: Molecular weight, reaction yields, and HPLC analytical data of compounds 1-7, Table S2: HRMS analytical data of compounds 1-7, Table S3: MS/MS analytical data of compounds 1-7.

Author Contributions: Conceptualization, A.K.P., Y.L., and A.M.; Methodology, A.K.P., P.S., and Y.L.; Formal analysis, A.K.P. and P.S.; Investigation, A.K.P. and P.S.; Writing-original draft preparation, A.K.P. and P.S.; Writing-review and editing, A.M., Y.L., F.R., O.H., and G.H.; Supervision, A.M. and Y.L.; Funding acquisition, A.K.P. and A.M. All authors have read and agreed to the published version of the manuscript.

Funding: This work was supported by grant no. 2017/27/N/NZ7/02473 and 2019/33/B/NZ7/02818 from the Narodowe Centrum Nauki (National Science Centre, Poland).

Acknowledgments: LC and MS analysis were partially done in the Laboratory of Chemical Synthesis, CePT, Mossakowski Medical Research Centre, co-financed by the EU from the European Regional Development Fund under the Operational Programme Innovative Economy, 2007-2013.

Conflicts of Interest: The authors declare no conflicts of interest.

\section{References}

1. He, Z.; Tessier-Lavigne, M. Neuropilin is a receptor for the axonal chemorepellent Semaphorin III. Cell 1997, 90, 739-751. [CrossRef] 
2. Lee, P.; Goishi, K.; Davidson, A.J.; Mannix, R.; Zon, L.; Klagsbrun, M. Neuropilin-1 is required for vascular development and is a mediator of VEGF-dependent angiogenesis in zebrafish. Proc. Natl. Acad. Sci. USA 2002, 99, 10470-10475. [CrossRef] [PubMed]

3. Staton, C.A.; Kumar, I.; Reed, M.W.; Brown, N.J. Neuropilins in physiological and pathological angiogenesis. J. Pathol. 2007, 212, 237-248. [CrossRef] [PubMed]

4. Zachary, I.C. How neuropilin-1 regulates receptor tyrosine kinase signalling: the knowns and known unknowns. Biochem. Soc. Trans. 2011, 39, 1583-1591. [CrossRef] [PubMed]

5. Mamluk, R.; Gechtman, Z.; Kutcher, M.E.; Gasiunas, N.; Gallagher, J.; Klagsbrun, M. Neuropilin-1 binds vascular endothelial growth factor 165 , placenta growth factor-2, and heparin via its b1b2 domain. J. Biol. Chem. 2002, 277, 24818-24825. [CrossRef] [PubMed]

6. Hicklin, D.J.; Ellis, L.M. Role of the vascular endothelial growth factor pathway in tumor growth and angiogenesis. J. Clin. Oncol. 2005, 23, 1011-1027. [CrossRef]

7. Guo, H.F.; Vander Kooi, C.W. Neuropilin functions as an essential cell surface receptor. J. Biol. Chem. 2015, 290, 29120-29126. [CrossRef]

8. Miao, H.Q.; Lee, P.; Lin, H.; Soker, S.; Klagsbrun, M. Neuropilin-1 expression by tumor cells promotes tumor angiogenesis and progression. FASEB J. 2000, 14, 2532-2539. [CrossRef]

9. Soker, S.; Takashima, S.; Miao, H.Q.; Neufeld, G.; Klagsbrun, M. Neuropilin-1 is expressed by endothelial and tumor cells as an isoform-specific receptor for vascular endothelial growth factor. Cell 1998, 92, 735-745. [CrossRef]

10. Kawakami, T.; Tokunaga, T.; Hatanaka, H.; Kijima, H.; Yamazaki, H.; Abe, Y.; Osamura, Y.; Inoue, H.; Ueyama, Y.; Nakamura, M. Neuropilin 1 and neuropilin 2 co-expression is significantly correlated with increased vascularity and poor prognosis in nonsmall cell lung carcinoma. Cancer 2002, 95, 2196-2201. [CrossRef]

11. Bagri, A.; Tessier-Lavigne, M.; Watts, R.J. Neuropilins in tumor biology. Clin. Cancer Res. 2009, 15, 1860-1864. [CrossRef]

12. Prud'homme, G.J.; Glinka, Y. Neuropilins are multifunctional coreceptors involved in tumor initiation, growth, metastasis and immunity. Oncotarget 2012, 9, 921-939. [CrossRef]

13. Wild, J.R.L.; Staton, C.A.; Chapple, K.; Corfe, B.M. Neuropilins: expression and roles in the epithelium. Int. J. Exp. Pathol. 2012, 93, 81-103. [CrossRef]

14. Keyt, B.A.; Berleau, L.T.; Nguyen, H.V.; Chen, H.; Heinsohn, H.; Vandeln, R.; Ferrara, N. The carboxyl-terminal domain (111-165) of vascular endothelial growth factor is critical for its mitogenic potency. J. Biol. Chem. 1996, 271, 7788-7795. [CrossRef]

15. Soker, S.; Gollamudi-Payne, S.; Fidder, H.; Charmahelli, H.; Klagsbrun, M. Inhibition of vascular endothelial growth factor (VEGF)-induced endothelial cell proliferation by a peptide corresponding to the exon 7-encoded domain of VEGF165. J. Biol. Chem. 1997, 272, 31582-31588. [CrossRef]

16. Fairbrother, W.J.; Chample, M.A.; Christinger, H.W.; Keyt, B.A.; Starovasnik, M.A. Solution structure of the heparin-binding domain of vascular endothelial growth factor. Structure 1998, 6, 637-648. [CrossRef]

17. Parker, M.W.; Xu, P.; Li, X.; Vander Kooi, C.W. Structural basis for selective vascular endothelial growth factor-A (VEGF-A) binding to neuropilin-1. J. Biol. Chem. 2012, 14, 11082-11089. [CrossRef]

18. Teesalu, T.; Sugahara, K.N.; Kotamraju, V.R.; Ruoslahti, E. C-end rule peptides mediate neuropilin-1-dependent cell, vascular, and tissue penetration. Proc. Natl. Acad. Sci. USA 2009, 106, 16157-16162. [CrossRef]

19. Binétruy-Tournaire, R.; Demangel, C.; Malavaud, B.; Vassy, R.; Rouyre, S.; Kraemer, M.; Plouët, J.; Derbin, C.; Perret, G.; Mazié, J.C. Identification of a peptide blocking vascular endothelial growth factor (VEGF)-mediated angiogenesis. EMBO J. 2000, 19, 1525-1533. [CrossRef]

20. Perret, G.Y.; Starzec, A.; Hauet, N.; Vergote, J.; Le Pecheur, M.; Vassy, R.; Léger, G.; Verbeke, K.A.; Bormans, G.; Nicolas, P.; et al. In vitro evaluation and biodistribution of a $99 \mathrm{mTc}$-labeled anti-VEGF peptide targeting neuropilin-1. Nucl. Med. Biol. 2004, 31, 575-581. [CrossRef]

21. Starzec, A.; Vassy, R.; Martin, A.; Lecouvey, M.; Di Benedetto, M.; Crépin, M.; Perret, G.Y. Antiangiogenic and antitumor activities of peptide inhibiting the vascular endothelial growth factor binding to neuropilin-1. Life Sci. 2006, 79, 2370-2381. [CrossRef] 
22. Fedorczyk, B.; Lipiński, P.F.J.; Tymecka, D.; Puszko, A.K.; Wilenska, B.; Perret, G.Y.; Misicka, A. Conformational latitude - activity relationship of KPPR tetrapeptide analogues toward their ability to inhibit binding of vascular endothelial growth factor 165 to neuropilin-1. J. Pept. Sci. 2017, 23, 445-454. [CrossRef]

23. Von Wronski, M.A.; Raju, N.; Pillai, R.; Bogdan, N.J.; Marinelli, E.R.; Nanjappan, P.; Ramalingam, K.; Arunachalam, T.; Eaton, S.; Linder, K.E.; et al. Tuftsin binds neuropilin-1 through a sequence similar to that encoded by exon 8 of vascular endothelial growth factor. J. Biol. Chem. 2006, 281, 5702-5710. [CrossRef]

24. Sugahara, K.N.; Teesalu, T.; Karmali, P.P.; Kotamraju, V.R.; Agemy, L.; Girard, O.M.; Hanahan, D.; Mattrey, R.F.; Ruoslahti, E. Tissue-penetrating delivery of compounds and nanoparticles into tumors. Cancer Cell 2009, 16, 510-520. [CrossRef]

25. Ghez, D.; Lepelletier, Y.; Lambert, S.; Fourneau, J.M.; Blot, V.; Janvier, S.; Arnulf, B.; van Endert, P.M.; Heveker, N.; Pique, C.; et al. Neuropilin-1 is involved in human T-cell lymphotropic virus type 1 entry. J. Virol. 2006, 80, 6844-6854. [CrossRef]

26. Lambert, S.; Bouttier, M.; Vassy, R.; Seigneuret, M.; Petrow-Sadowski, C.; Janvier, S.; Heveker, N.; Ruscetti, F.W.; Perret, G.; Jones, K.S.; et al. HTLV-1 uses HSPG and neuropilin-1 for entry by molecular mimicry of VEGF165. Blood 2009, 113, 5176-5185. [CrossRef]

27. Wang, H.B.; Zhang, H.; Zhang, J.P.; Li, Y.; Zhao, B.; Feng, G.K.; Du, Y.; Xiong, D.; Zhong, Q.; Liu, W.L.; et al. Neuropilin 1 is an entry factor that promotes EBV infection of nasopharyngeal epithelial cells. Nat. Commun. 2015, 6, 6240. [CrossRef] [PubMed]

28. Li, X.; Pontén, A.; Aase, K.; Karlsson, L.; Abramsson, A.; Uutela, M.; Bäckström, G.; Hellström, M.; Boström, H.; Li, H.; et al. PDGF-C is a new protease-activated ligand for the PDGF alpha-receptor. Nat. Cell. Biol. 2000, 2, 302-309. [CrossRef] [PubMed]

29. Liu, W.Q.; Borriello, L.; Allain, B.; Pavoni, S.; Lopez, N.; Hermine, O.; Garbay, C.; Raynaud, F.; Lepelletier, Y.; Demange, L. New Peptides Structurally Related to VEGF-A165 Exon-7 and -8 Encoded Domains Antagonize Its Binding to NRP-1 and VEGF-R1. Int. J. Pept. Res. Ther. 2015, 21, 117-124. [CrossRef]

30. Wennmohs, F.; Staemmler, V.; Schindler, M. Theoretical investigation of weak hydrogen bonds to sulfur. J. Chem. Phys. 2003, 119, 3208-3218. [CrossRef]

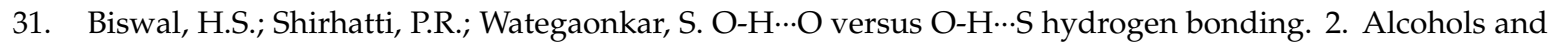
thiols as hydrogen bond acceptors. J. Phys. Chem. A 2010, 114, 6944-6955. [CrossRef] [PubMed]

32. Ringer, A.L.; Senenko, A.; Sherrill, C.D. Models of S/pi Interactions in Protein Structures: Comparison of the H2S Benzene Complex With PDB Data. Protein Sci. 2007, 16, 2216-2223. [CrossRef]

33. Daeffler, K.N.-M.; Lester, H.A.; Dougherty, D.A. Functionally Important Aromatic-Aromatic and Sulfur- $\pi$ Interactions in the D2 Dopamine Receptor. J. Am. Chem. Soc. 2012, 134, 14890-14896. [CrossRef] [PubMed]

34. Drobecq, H.; Boll, E.; Sénéchal, M.; Desmet, R.; Saliou, J.M.; Lacapère, J.J.; Mougel, A.; Vicogne, J.; Melnyk, O. A Central Cysteine Residue Is Essential for the Thermal Stability and Function of SUMO-1 Protein and SUMO-1 Peptide-Protein Conjugates. Bioconjug. Chem. 2016, 27, 1540-1546. [CrossRef] [PubMed]

35. Putzu, M.; Gräter, F.; Elstner, M.; Kubař, T. On the Mechanism of Spontaneous Thiol-Disulfide Exchange in Proteins. Phys. Chem. Chem. Phys. 2018, 20, 16222-16230. [CrossRef]

36. Passam, F.J.; Chiu, J. Allosteric Disulphide Bonds as Reversible Mechano-Sensitive Switches That Control Protein Functions in the Vasculature. Biophys. Rev. 2019, 11, 419-430. [CrossRef]

37. Tymecka, D.; Puszko, A.K.; Lipiński, P.F.; Fedorczyk, B.; Wileńska, B.; Sura, K.; Perret, G.Y.; Misicka, A. Branched Pentapeptides as Potent Inhibitors of the Vascular Endothelial Growth Factor 165 Binding to Neuropilin-1: Design, Synthesis and Biological Activity. Eur. J. Med. Chem. 2018, 158, 453-462. [CrossRef]

38. Puszko, A.K.; Sosnowski, P.; Tymecka, D.; Raynaud, F.; Hermine, O.; Lepelletier, Y.; Misicka, A. Neuropilin-1 Peptide-Like Ligands With Proline Mimetics, Tested Using the Improved Chemiluminescence Affinity Detection Method. Med. Chem. Comm. 2019, 10, 332-340. [CrossRef]

39. Allain, B.; Jarray, R.; Borriello, L.; Leforban, B.; Dufour, S.; Liu, W.Q.; Pamonsinlapatham, P.; Bianco, S.; Larghero, J.; Hadj-Slimane, R.; et al. Neuropilin-1 Regulates a New VEGF-induced Gene, Phactr-1, Which Controls Tubulogenesis and Modulates Lamellipodial Dynamics in Human Endothelial Cells. Cell Signal. 2012, 24, 214-223. [CrossRef]

40. Borriello, L.; Montès, M.; Lepelletier, Y.; Leforban, B.; Liu, W.Q.; Demange, L.; Delhomme, B.; Pavoni, S.; Jarray, R.; Boucher, J.L.; et al. Structure-based Discovery of a Small Non-Peptidic Neuropilins Antagonist Exerting in Vitro and in Vivo Anti-Tumor Activity on Breast Cancer Model. Cancer Lett. 2014, 349, 120-127. [CrossRef] 
41. Puszko, A.K.; Sosnowski, P.; Pułka-Ziach, K.; Hermine, O.; Hopfgartner, G.; Lepelletier, Y.; Misicka, A. Urea Moiety as Amide Bond Mimetic in Peptide-Like Inhibitors of VEGF-A $165 /$ NRP-1 Complex. Bioorg. Med. Chem. Lett. 2019, 29, 2493-2497. [CrossRef]

42. Carpino, L.A.; Han, G. 9-Fluorenylmethoxycarbonyl amino-protecting group. J. Org. Chem. 1972, 37, 3404-3409. [CrossRef]

43. Carpino, L.A. 1-Hydroxy-7-azabenzotriazole. An efficient peptide coupling additive. Am. Chem. Soc. 1993, 115, 4397-4398. [CrossRef]

44. Starzec, A.; Ladam, P.; Vassy, R.; Badache, S.; Bouchemal, N.; Navaza, A.; du Penhoat, C.H.; Perret, G.Y. Structure-function Analysis of the Antiangiogenic ATWLPPR Peptide Inhibiting VEGF(165) Binding to neuropilin-1 and Molecular Dynamics Simulations of the ATWLPPR/neuropilin-1 Complex. Peptides 2007, 28, 2397-2402. [CrossRef]

45. Vander Kooi, C.W.; Jusino, M.A.; Perman, B.; Neau, D.B.; Bellamy, H.D.; Leahy, D.J. Structural Basis for Ligand and Heparin Binding to Neuropilin B Domains. PNAS 2007, 104, 6152-6157. [CrossRef]

46. Kamarulzaman, E.E.; Vanderesse, R.; Gazzali, A.M.; Barberi-Heyob, M.; Boura, C.; Frochot, C.; Shawkataly, O.; Aubry, A.; Wahab, H.A. Molecular Modelling, Synthesis and Biological Evaluation of Peptide Inhibitors as Anti-Angiogenic Agent Targeting neuropilin-1 for Anticancer Application. J. Biomol. Struct. Dyn. 2017, 35, 26-45. [CrossRef]

47. Rawlings, N.D. Peptidase Specificity From the Substrate Cleavage Collection in the MEROPS Database and a Tool to Measure Cleavage Site Conservation. Biochimie 2016, 122, 5-30. [CrossRef]

48. De Vriese, C.; Gregoire, F.; Lema-Kisoka, R.; Waelbroeck, M.; Robberecht, P.; Delporte, C. Ghrelin degradation by serum and tissue homogenates: identification of the cleavage sites. Endocrinology 2004, 145, 4997-5005. [CrossRef]

49. Mansfeld, F.M.; Toth, I. Synthesis and Plasma Stability of Disulfide-Bridged Cyclic Endomorphin-1 Derivatives. Int. J. Org. Chem. 2012, 2, 1-6. [CrossRef]

50. Nguyen, L.T.; Chau, J.K.; Perry, N.A.; de Boer, L.; Zaat, S.A.; Vogel, H.J. Serum stabilities of short tryptophanand arginine-rich antimicrobial peptide analogs. PLOS ONE 2010, 5, e12684. [CrossRef]

51. Janecka, A.; Kruszynski, R.; Fichna, J.; Kosson, P.; Janecki, T. Enzymatic degradation studies of endomorphin-2 and its analogs containing N-methylated amino acids. Peptides 2006, 27, 131-135. [CrossRef] 